\title{
Et Øst-Vest skille for eldres livskvalitet i Europa? En sammenligning av ensomhet og depressive symptomer $i$ 12 land
}

\author{
Thomas Hansen* \& Britt Slagsvold \\ Velferdsforskningsinstituttet NOVA, OsloMet - Storbyuniversitetet
}

\begin{abstract}
An East-West divide in late-life wellbeing in Europe? A comparative study of 12 countries

This study explores late-life loneliness and depression in European countries, noting the role of micro-level differences in socioeconomic status, health, and social variables. Findings from cross-sectional, nationally representative data from 12 countries and 36,000 individuals in the Generations and Gender Survey show a marked East-West divide among older but not among younger adults. Among older adults (aged 60-80) loneliness and depression are as much as three to four times more prevalent in Eastern European (20-40\%) than in Northwest European countries (10-15\%). These patterns reflect economic, social, and societal issues which in turn affect the conditions for active and healthy aging. There is considerable variation among Eastern European countries, correlating with macro-level economic development and welfare spending. Generous welfare states seem to offer a buffer against, or postpone, the risk of late-life depression and loneliness. Cultural factors may also play a role: because of high expectations as to strong family and community ties, Eastern Europeans may have a lower loneliness threshold than other Europeans.
\end{abstract}

Keywords: aging, mental health, depression, Eastern Europe

I denne artikkelen undersøker vi landsforskjeller i forekomsten av ensomhet og depressive symptomer blant eldre personer i 12 europeiske land. Er det empirisk belegg for å skille mellom «Øst» og «Vest», og hva kan eventuelt forklare forskjellene?

Ensomhet og depressive symptomer blir av mange ansett som «normale» problemer i eldre år, som alderdommens naturlige følgesvenner (Tornstam, 2007). Ensomhet kan defineres som en negativ, følelsesmessig opplevelse som springer ut av misforholdet mellom ønskede og faktiske sosiale relasioner (De Jong Gierveld, van Tilburg \& Dykstra, 2006). Depresjon og depressive symptomer kjennetegnes ved nedstemthet,

\footnotetext{
`Kontaktinformasjon: Thomas Hansen, epost: thomas.hansen@oslomet.no 
interesse- og gledeløshet og tap av energi (WHO, 1993). ${ }^{1}$ Antakelsene om at aldring innebærer mer ensomhet og depresjon gir mening $i$ lys av at høy alder vanligvis innebærer svekkelser eller tap assosiert med slike problemer, som redusert helse, kognitiv funksjon, sosialt nettverk og sosioøkonomiske ressurser (Fiske, Wetherell \& Gatz, 2009). Forskningslitteraturen viser imidlertid at forekomstene av ensomhet og depresjon er nokså stabile langt inn i alderdommen, men at de øker sterkt helt mot slutten av livet. Ensomhet oppgis av om lag 5-15\% i alderen 60 til 80, men er langt mer utbredt (40-50 \%) blant de over 80 år (Dykstra, 2009). Tilsvarende viser mange studier at depressive symptomer er nokså stabile mellom om lag 50 til 65 år (8-18\%) men stiger jevnt i eldre aldergrupper (Blazer, 2003; Hansen \& Slagsvold, 2011a, 2012; Sutin, Terracciano \& Milaneschi, 2013).

Denne forskningslitteraturen domineres imidlertid av data fra rike, vestlige land med generøse velferdsordninger. Aldersrelaterte økninger i ensomhet og depressive plager kan tenkes å være sterkere og opptre tidligere i land med dårligere livsbetingelser. Dette fordi eldre i svake velferdsstater kan være mer eksponert og mer sårbare for ulike risikofaktorer. Sterkere velferdsstater kan forhindre eller redusere psykiske helseproblemer for eksempel gjennom bedre helse- og sosiale tjenester, bedre inntekts- og boligforhold, tilgjengelig offentlig transport og støtte til familieomsorgsgivere. På grunn av mangel på sammenlignbare data foreligger det få komparative analyser på tvers av land. Kunnskap om eldres livskvalitet er spesielt mangelfull i Øst-Europa, en region med særlige utfordringer knyttet til å møte eldres materielle, sosiale og helsemessige behov (Botev, 1999, 2012).

Risikofaktorer for ensomhet og depresjon i eldre år er - med stor variasjon mellom land - særlig utbredt i de tidligere kommuniststatene i Øst-Europa. For eksempel rapporterer mange pensjonister om økonomiske vansker (se Appendiks for utvalgte demografiske og økonomiske data for landene som benyttes i den foreliggende studien). Vanskelighetene ble mer utbredt etter kommunistregimenes fall på grunn av økende inflasjon og synkende pensjonsverdier (Botev, 2012). Videre rapporterer østeuropeiske eldre å ha langt dårligere helse og lavere levealder enn seniorer i Vest, noe som skyldes en kombinasjon av usunn livsstil (f.eks. høyt alkoholforbruk blant menn), psykososiale risikofaktorer (stress og mangel på kontroll) og dårlig tilgang til gode helsetjenester (Deaton, 2007; Yakovlev, 2015). Østeuropeiske eldre møter også ulike sosiale utfordringer. På grunn av lav levealder blant menn er svært mange eldre østeuropeiske kvinner enker (Botev, 2012). I tillegg fører synkende barnetall og økende utflytting av yngre voksne (OECD, 2012) til at mange eldre mangler barn og barnebarn som kan ta vare på dem. Det å ha barn som bor langt unna kan også i seg selv føre til nedstemthet og depressive plager.

Den tilgjengelige tverrnasjonale europeiske litteraturen bekrefter i stor grad at ensomhet og depresjon i senlivet er mer utbredt i land med lavere velstand og

${ }^{1}$ For å lette lesingen bruker vi ofte termen «depresjon» for å indikere (klinisk relevante) depressive symptomer. Det er imidlertid depressive symptomer som måles i artikkelen og ikke klinisk depresjon. 
levekår. Studier basert på SHARE-undersøkelsen (alder 50+), som dekker land fra Nord-Europa til Middelhavsregionen, viser at det er flere ensomme (Fokkema et al., 2012; Sundstrom et al., 2009) og deprimerte (Castro-Costa et al., 2007; Kok et al., 2012) eldre i Sør- og Sentral-Europa enn i Nordvest-Europa. Studier av eldre personer $(60+)$ i European Social Survey bekrefter dette mønsteret for ensomhet (Yang \& Victor, 2011) og depresjon (Van de Velde et al., 2010). To studier har studert ensomhet i seks europeiske land fra Generations and Gender Survey (GGS) (60-79 år) (De Jong Gierveld, Dykstra \& Schenk, 2012; De Jong Gierveld \& Van Tilburg, 2010). Studiene viser at ensomhetsnivåne er klart høyere i de østeuropeiske (Bulgaria, Georgia og Russland) enn i de vesteuropeiske landene (Frankrike, Tyskland og Nederland).

I den foreliggende studien utforskes utbredelsen av ensomhet og depresion $\mathrm{i}$ 12 land.Vi sammenligner land fra Øst-Europa med Nord- og Vest-Europa, her også referert til som «Øst-Vest». For å få et samlet bilde av hvordan aldersforskjeller i ensomhet og depresjon varierer mellom land og hvorvidt ulikhet i eldres plager er unik for denne aldersgruppen, rapporterer vi først de landsspesifikke utbredelsene $\mathrm{i}$ aldersgrupper mellom 18 og 80 år. Dernest, siden vårt primære fokus er "de eldre», fokuserer vi på aldersgruppen 60-80 og undersøker mønstre og faktorer som kan bidra til å forklare tverrnasjonale forskjeller. Vi ser særlig på sosioøkonomisk status, sosialt nettverk og fysisk helse som forklaringsfaktorer. Hovedformålet med studien er å undersøke om ulike livsbetingelser og forutsetningene for aktiv og god aldring lar seg oversette til regionale skiller i utbredelsen av ensomhet og depresion blant eldre i Europa. Ensomhet og depressive symptomer er målt med etablerte og kryss-kulturelt validerte flerleddsinstrument.

\section{Metode}

Datagrunnlaget er tverrsnittsdata fra første runde av GGS (Vikat et al., 2007), som inneholder landsrepresentative og harmoniserte data fra personer mellom 18 og 80 år i 19 land i Europa. Vi benytter data fra 12 land som har samlet inn data om ensomhet og depresjon, hvorav sju er østeuropeiske (Bulgaria, Polen, Tsjekkia, Georgia, Litauen, Romania og Russland) og fem er nordvesteuropeiske land (Belgia, Frankrike, Norge, Sverige, Tyskland). Samlet svarprosent for GGS landene er nærmere 60 $\%$, med ytterpunktene Litauen (37 \%) og Romania (84\%) (Fokkema et al., 2016). Samlet svarprosent for de 12 landene som brukes her er $68 \%$ (Fokkema et al., 2014). Polen og Tyskland mangler depresjonsdata, derfor bygger analysene av depresjon på 10 land fremfor 12. Datamaterialet er innsamlet i perioden mellom 2005 og 2012, gjennom personlige intervjuer i alle land unntatt Norge og Sverige. I Norge og Sverige ble det benyttet telefonintervju og postalt spørreskjema (Hansen \& Slagsvold, 2011b). ${ }^{2}$ Den norske GGS ble gjennomført som del av andre runde av den norske studien om livsløp, aldring og generasjon (NorLAG) (Slagsvold et al., 2012).

${ }^{2}$ Ensomhet og depresjon ble målt i spørreskjemaet. 


\section{Avhengige variabler}

Ensomhet er målt ved en 6-ledd-versjon av den opprinnelige 11-ledd De Jong Gierveld Loneliness Scale (De Jong Gierveld et al., 2006). Skalaen har vist seg å ha gode psykometriske egenskaper og målingsekvivalens på tvers av land (De Jong Gierveld \& Van Tilburg, 2010). Skalaen inneholder tre positivt formulerte ledd ("Jeg er nært knyttet til mange nok mennesker»; «Det er mange jeg kan stole helt og fullt på»; "Det er mange jeg kan støtte meg til hvis jeg har problemer») og tre negativt formulerte ledd ("Jeg savner å ha folk rundt meg》; «Jeg føler meg ofte avvist»; "Jeg opplever en generell følelse av tomhet») med svarene «nei» (0), «mer eller mindre» (1) og «ja» (2). Etter å ha snudd de positive leddene laget vi en additiv indeks som går fra $0-12(\alpha=.75)$, hvor høye skårer indikerer høy grad av ensomhet. Vi lot skårer $\geq$ 6 indikere «ensomhet». Vi benyttet en grenseverdi som er høyere enn den konvensjonelle i forskningsfeltet, fordi vi er interessert i en mer alvorlig og problematisk grad av ensomhet (se Hansen \& Slagsvold, 2016).

Depressive symptomer er målt ved en 7-ledd-versjon av den 20-ledd Center for Epidemiologic Studies Depression Scale (CES-D) (Radloff, 1977). Det er det mest brukte instrumentet til å måle depressive symptomer og for å estimere prevalensrate (forekomst/utbredelse) i befolkningsundersøkelser (Shafer, 2006). CES-D er vist å være pålitelig og gyldig i forskjellige populasjoner, med høy intern konsistens og konstruktvaliditet (McDowell, 2006). Versjonen vi benytter har leddene "Jeg følte meg deprimert»; "Jeg tenkte at livet mitt hadde vært mislykket»; «Jeg var nedstemt og kunne ikke riste det av meg, til tross for støtte fra familie og venner»; "Jeg følte meg engstelig»; «Jeg følte meg ensom»; "Jeg følte meg trist»; og "Jeg gråt». Respondentene ble bedt å angi hvor ofte de følte seg slik den siste uken på en skala fra 0 (sjelden eller aldri) til 3 (hele eller nesten hele tiden). En indeks (0-21) ble konstruert $(\alpha=.89)$ der høy skår indikerer mer depressive symptomer.

For å identifisere personer med depressive symptomer benyttes en grenseverdi på 6 , hvilket tilsvarer den konvensjonelle grenseverdien på 16 på 20-ledd skalaen (0-60) (Moor \& Komter, 2012). Merk at CES-D måler depressive symptomer og ikke klinisk depresjon (i henhold til ICD-10 eller DSM-IV diagnostiske kriterier) (Fiske et al., 2009). Depressive symptomer er minst to til tre ganger mer utbredt enn klinisk depresjon blant eldre (Blazer, 2003; Fiske et al., 2009). Ensomhet og depressive symptomer er distinkte fenomen som vi analyserer separat. De er imidlertid nokså høyt korrelert ( $\mathrm{r}=.35-.41 \mathrm{i}$ våre landsutvalg), noe som reflekterer at de giensidig påvirker hverandre og har fellestrekk hva gjelder konseptuelt innhold og etiologi (årsaksfaktorer).

\section{Uavhengige variabler}

Vi kontrollerer for ulike individuelle kjennetegn assosiert med ensomhet og depresjon (Fiske et al., 2009; Pinquart \& Sorensen, 2001). I tillegg til kjønn og alder, 
inkluderes sivilstatus, som er delt i fire kategorier: aldri gift; gift/samboende; skilt; og enke. Vi inkluderer antall (biologiske) barn, da barn kan utgjøre en viktig kilde til sosial kontakt og støtte. I de multivariate analysene er barnetall over 3 kodet som 3. Helse refererer til subjektiv helsestatus, fra svært dårlig (1) til veldig bra (5). Tre sosioøkonomiske variabler er inkludert. Utdanning er klassifisert i følgende kategorier: lav (ISCED 0-2), medium (ISCED 3-4) og høy (ISCED 5-6). Yrkesaktiv (nei/ja) er inkludert da sysselsetting kan redusere psykiske plager gjennom økt deltakelse og tilgang på støtte, samt økt følelse av mening og nytte. Økonomisk situasjon (vansker med «å få endene til å møtes») varierer fra 1 (store vanskeligheter) til 5 (veldig enkelt).

\section{Analytisk metode}

Vi benytter kjikvadrat $\left(X^{2}\right)$ og $F$-tester for å sammenligne andeler og gjennomsnitt mellom land. Alle multivariate analyser bruker vanlige OLS regresjoner. Logistisk regresion i stedet for OLS er vanligvis foretrukket når avhengig variabel er binær. Imidlertid bruker vi OLS fordi de to metodene gir svært like resultater, og fordi OLS-koeffisientene gir lettere fortolkning (Hellevik, 2009). Vi har analysert med utgangspunkt $i$ en modell som bare inneholder landsdummier, kjønn og alder. I neste modell kontrollerer vi for sivilstand, antall barn, sosioøkonomiske indikatorer og helsevariabler (komposisjonelle effekter) for å undersøke om landforskjeller kan skyldes ulik eksponering for kjente risikofaktorer for ensomhet og depresjon.

\section{Resultater}

Figur 1 viser aldersforskjeller i utbredelsen av ensomhet for hvert land. Mens ensomhetsnivåene er nokså lave og stabile (5-15\%) på tvers av alder i de nordvesteuropeiske landene (unntatt blant de yngste i Sverige: $18 \%$ ), er det en klar positiv sammenheng mellom alder og ensomhet $\mathrm{i}$ de østeuropeiske landene. I de østeuropeiske landene, unntatt Polen, øker forekomsten fra 10-18\% blant de yngste til $27-47 \%$ blant de eldste. De største aldersforskjellene finner vi i Bulgaria (fra 18 til $45 \%$ ) og Georgia (fra 14 til $47 \%$ ). Som et resultat av kontrasten mellom stabilitet i Vest og økning i Øst oppstår markante regionale skiller i ensomhet i eldre aldersgrupper.

Det er verdt å merke seg de klare forskjellene mellom de østeuropeiske landene. Polen skiller seg tydeligst ut, med aldersrelaterte forekomster som ligner på de observert i de vestlige landene. Ensomheten i Polen stiger jevnt fra $6 \%$ blant de yngste til $15 \%$ blant de eldste. Russland og Tsjekkia plasserer seg midt imellom landene med høyest og lavest forekomst av ensomhet.

Kjønnsforskjeller fremgår ikke av figuren, men det er verdt å merke seg at mens det er små kjønnsforskjeller i de nordvestlige landene, rapporterer kvinner høyere forekomst av ensomhet (opptil 9 prosentpoeng) enn menn i de østeuropeiske landene (Hansen \& Slagsvold, 2016). 


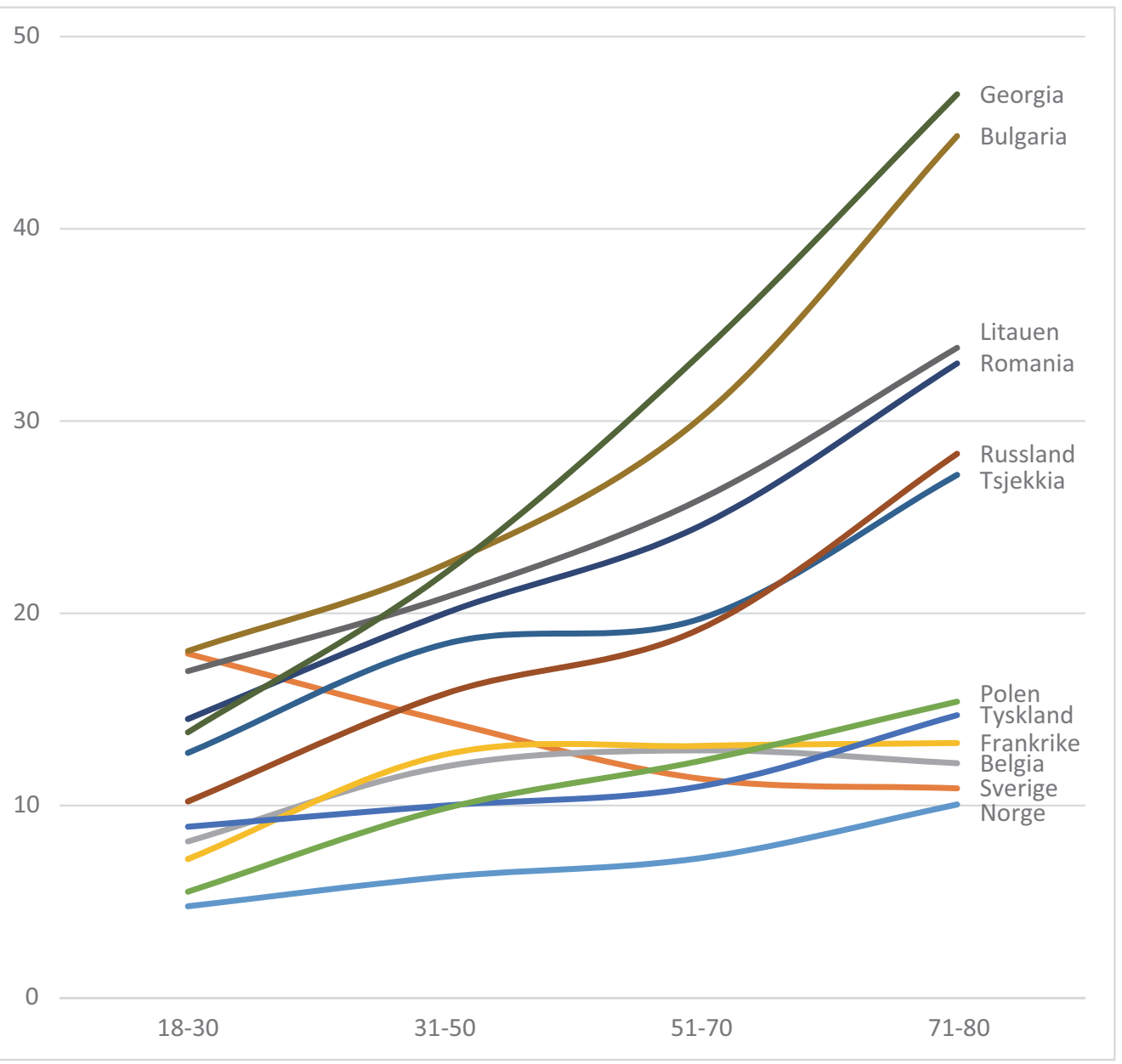

Figur 1. Andel (\%) ensomme etter alder og land.

Note: Prosentene er justert for kjønn. Tallene figuren baseres på kan fås av forfatterne på forespørsel.

Figur 2 viser utbredelsen av depressive symptomer etter alder og land. Med unntak av den høye forekomsten (24\%) blant de yngste svenskene, viser de nordvestlige landene ganske stabil forekomst (rundt 10-15\%) i alle aldersgrupper. Derimot viser de østeuropeiske landene betydelig høyere rater blant de eldste vis-à-vis de yngste; ratene mer enn firedobles i Georgia (fra $8 \%$ til $36 \%$ ) og Romania (8 \% til $33 \%$ ). To andre mønstre er bemerkelsesverdige og bør vies oppmerksomhet i fremtidig forskning. Det ene er lav forekomst av depressive symptomer blant yngre østeuropeere. Disse landene har de høyeste andeler med depresjon blant de eldste, men tenderer å ha de laveste blant de yngste. Det andre poenget er at depressive plager i Norge og særlig i Sverige er vanligere blant yngre enn eldre. Særlig det høye nivået blant yngre svensker bør vies oppmerksomhet i videre forskning. Kanskje skyldes 


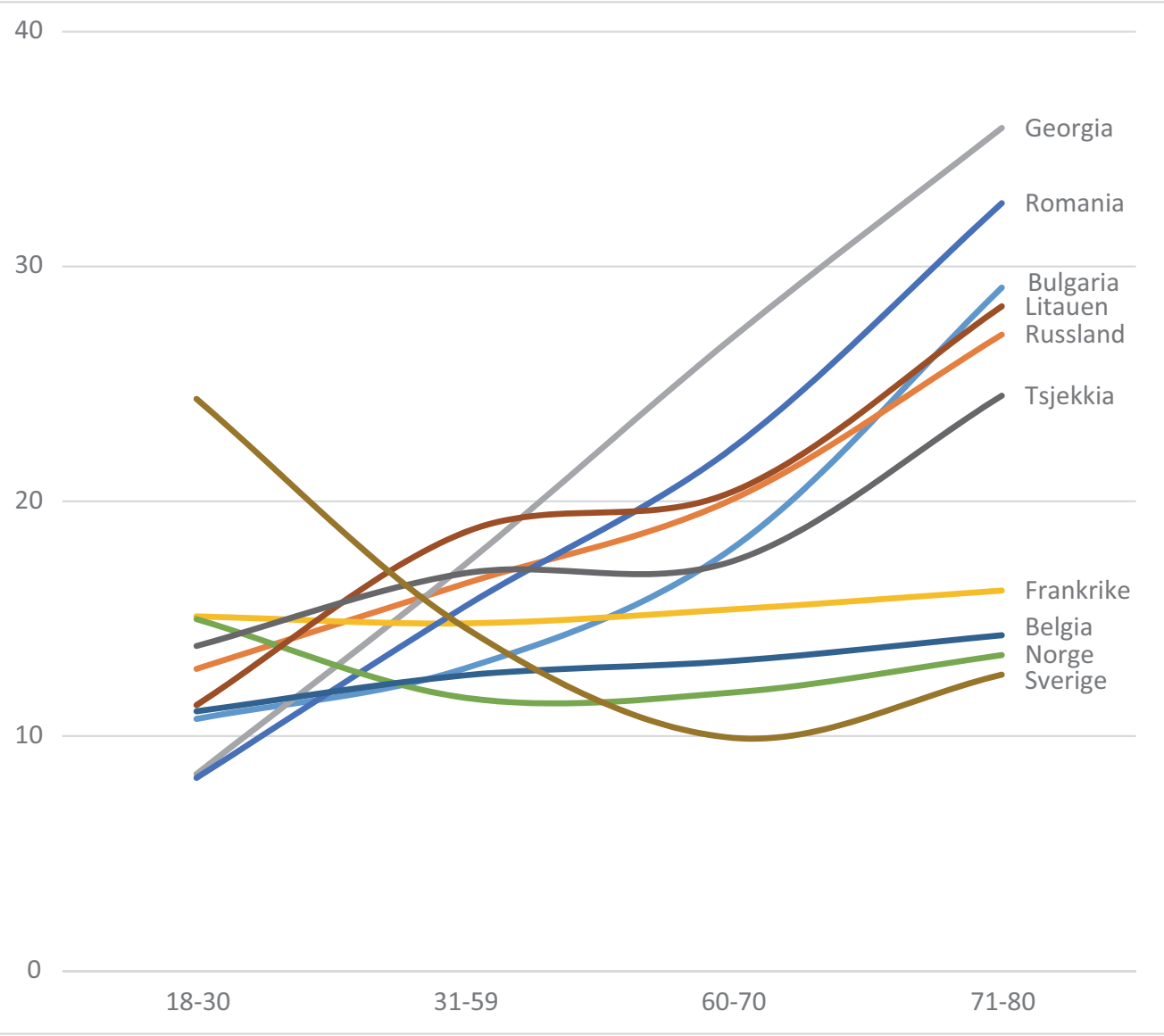

Figur 2. Andeler (\%) med depressive symptomer etter alder og land.

Note: Prosentene er justert for kjønn. Tallene figuren baseres på kan fås av forfatterne på forespørsel.

omfanget at psykiske plager har steget i disse aldersgruppene de siste årene, slik man har sett i Norge særlig blant jenter (Sletten \& Bakken, 2016).

Det er også interessant at depresjonsratene er omtrent dobbelt så høye blant kvinner som blant menn $\mathrm{i}$ alle land (fremgår ikke av figuren, men se Hansen \& Slagsvold, 2017). Målt i absolutte tall er forskjellene størst i de østeuropeiske landene, hvor kvinner rapporterer opptil 20 prosentpoeng høyere rater enn menn. Kjønnsforskjellen blant 70 -åringer er størst i Romania (19 vs. 37 \%) og Georgia (21 vs. $41 \%)$. Depresjonsnivåene blant østeuropeiske kvinner skyldes sannsynligvis - i tillegg til faktorer vi kommer tilbake til - at relativt mange er enker på grunn av lav levealder blant menn (ibid.). Det er også verdt å merke seg at det er klare utdanningsgradienter $i$ ensomhet og depresjon blant eldre menn og kvinner $i$ alle land, men særlig i de østeuropeiske landene (Hansen et al., 2017). For eksempel ser vi den største kontrasten i depresjon mellom høyt utdannede menn i Norden, hvor kun 4-5\% 
oppgir slike plager, og lavere utdannede østeuropeiske kvinner, hvor opptil $45 \%$ rapporterer slike plager (ibid.). Det er altså en «firedobbel fare» for psykiske plager assosiert med å være eldre, kvinne, lavere utdannet og østeuropeisk.

I det følgende fokuserer vi på aldersgruppen 60-80 år og utforsker mønstre og forklaringsfaktorer for tverrnasjonale forskjeller i ensomhet og depressive symptomer. Tabell 1 viser beskrivende statistikk for avhengige og uavhengige variabler vi bruker $i$ analysene for hvert land. Nederst $i$ tabellen ser vi at vestlige eldre er langt sjeldnere ensomme og deprimerte enn eldre i øst. Andelen ensomme varierer fra $8,3 \%$ i Norge til $42,5 \%$ i Georgia, og andelen deprimerte varierer fra 10,7 \% i Sverige til 30,8 \% i Georgia. Gjennomsnittlig alder i utvalgene er nokså lik på tvers av landene. Videre ser vi at det er markante nasjonale forskjeller i eldres sivilstatus og barnetall. Eldre i Vest lever langt oftere med en partner og har i gjennomsnitt flere barn enn eldre i Øst. Andelen etterlatte varierer markant, fra 5,8 \% i Sverige til 31,4 \% i Litauen. Eldre i Vest er også mer fornøyde med økonomien, har høyere utdannelse og er oftere yrkesaktive. Disse forskjellene er betydelige. For eksempel rapporterer kun $1-4 \%$ av eldre i de vestlige landene om «store problemer» med å få endene til å møtes, hvilket er langt færre enn i land som Romania (20\%), Russland (32\%), Bulgaria (43\%) og Georgia (43\%) (Hansen \& Slagsvold, 2016). Eldre i Vest rapporterer også bedre helse enn eldre i Øst.

Tabell 2 viser resultatene fra regresjonsanalyser der vi ser på landsforskjeller (med Norge som referanse) i eldres ensomhet og depressive symptomer. Modell 1, som kontrollerer kun for kjønn og alder, viser at eldre i de nordvestlige landene rapporterer signifikant lavere forekomst av plager med ensomhet og depresjon enn jevnaldrende i de østlige landene. Her ser vi også at plagene er assosiert med høy alder og det å være kvinne. I modell 2 tas det hensyn også til de andre risikofaktorene. Vi ser at ensomhet og depresjon er assosiert med det å være enslig (skilt eller etterlatt) og ikke yrkesaktiv, og å ha få barn (signifikant for depresjon), økonomiske problemer, lav utdanning (signifikant for depresjon), dårlig helse. De klart mest betydningsfulle forklaringsfaktorene er helse og sivilstand. For eksempel er det å være skilt eller enke(mann) assosiert med 10-15 prosentpoeng høyere forekomst av ensomhet og depresjon sammenlignet med å være gift/samboende. Effekten av helse er også betydningsfull; én skår høyere på helsevariabelen (som går fra 1-5) er assosiert med 10-13 prosentpoeng lavere forekomst av ensomhet og depresjon.

Når det gjelder den endelige modellen for ensomhet ser vi at risikofaktorene kun delvis forklarer den høye forekomsten i Øst-Europa. Selv når vi tar hensyn til de ulike risikofaktorene har østeuropeiske eldre en klart høyere forekomst av ensomhet enn eldre i Vest. Når vi justerer for disse risikofaktorene forsvinner eller reverseres landsforskjellene i depresjon. Det mest ekstreme eksemplet er Georgia, som i modell 1 er assosiert med 19 prosentpoeng høyere depresjonsrate, men 7 prosentpoeng lavere rate i den endelige modellen. Dette kan fortolkes som at eldre i Øst - dersom de hadde levekår lik det europeiske gjennomsnittet for sin aldersgruppe - rimeligvis (ettersom dette nivået ligger klart over hva som er vanlig i Øst) ville rapportert et 


\section{HANSEN \& SLAGSVOLD}

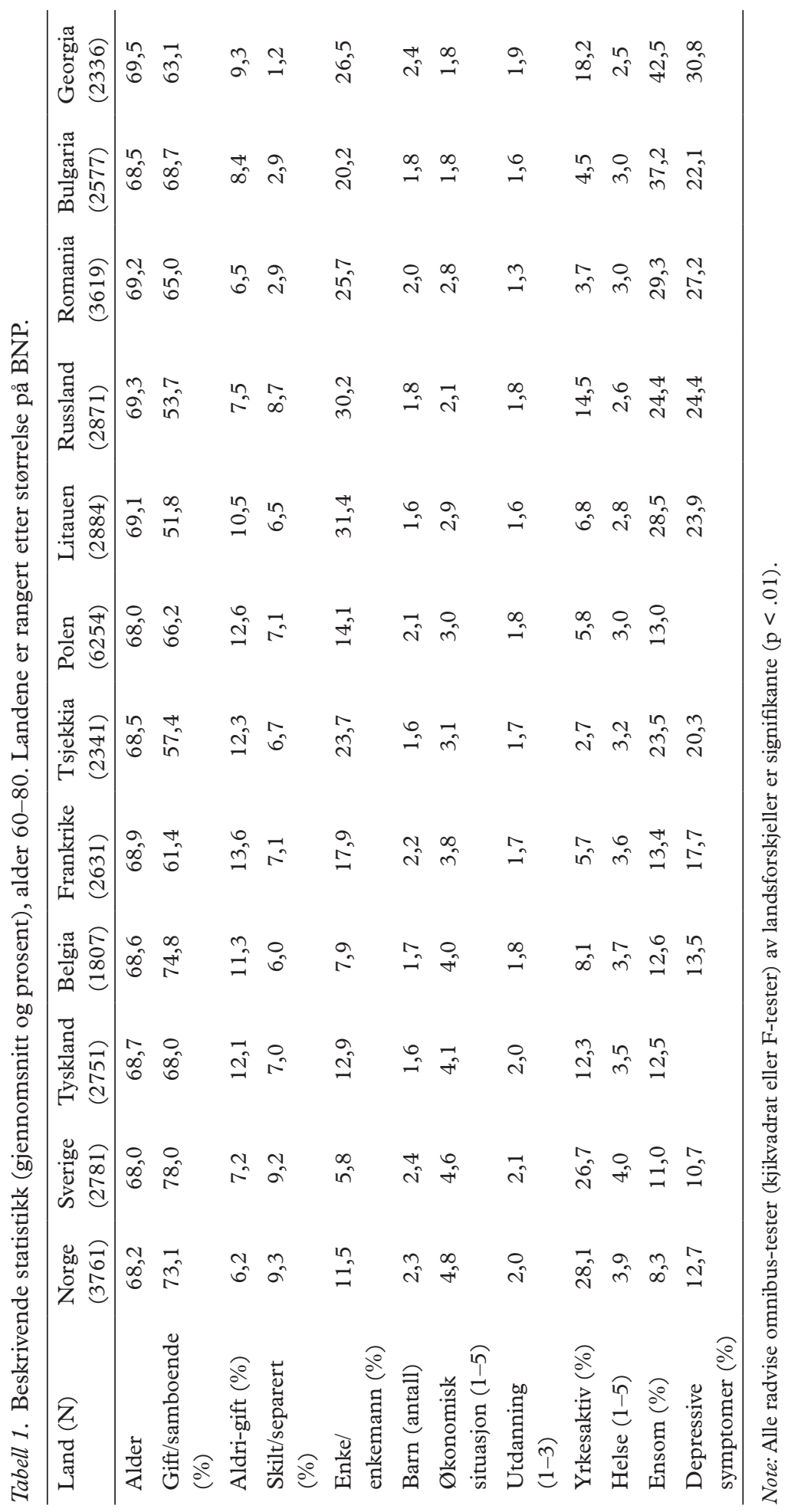


Tabell 2. Multivariat regresjon av ensomhet og depressive symptomer (0/1) blant personer i alderen 60-80 år. Ustandardiserte koeffisienter.

\begin{tabular}{|c|c|c|c|c|}
\hline & \multicolumn{2}{|c|}{ Ensomhet } & \multicolumn{2}{|c|}{ Depressive symptomer } \\
\hline & Modell 1 & Modell 2 & Modell 1 & Modell 2 \\
\hline \multicolumn{5}{|l|}{ Norge (ref.) } \\
\hline Sverige & 0.03 & 0.01 & -0.01 & 0.01 \\
\hline Tyskland & 0.04 夫 & -0.02 & & \\
\hline Belgia & 0.04 夫 & -0.02 & $0.02^{\star}$ & -0.02 \\
\hline Frankrike & $0.06^{\star \star}$ & 0.00 & $0.06^{\star \star}$ & -0.03 \\
\hline Tsjekkia & $0.15^{\star \star}$ & $0.10^{\star \star}$ & $0.09^{\star \star}$ & $-0.06^{\star}$ \\
\hline Polen & $0.05 \star \star$ & 0.00 & & \\
\hline Litauen & $0.20^{\star \star}$ & $0.13^{\star \star}$ & $0.12^{\star \star}$ & $-0.09^{\star}$ \\
\hline Russland & $0.18 \star \star$ & $0.11^{\star \star}$ & $0.13^{\star \star}$ & $-0.07^{\star}$ \\
\hline Romania & $0.29 \star \star$ & $0.13^{\star \star}$ & $0.16^{\star \star}$ & $-0.05^{\star}$ \\
\hline Bulgaria & $0.30 \star \star$ & $0.15^{\star \star}$ & $0.12^{\star \star}$ & $-0.06^{\star}$ \\
\hline Georgia & $0.34 \star \star \star$ & $0.16^{\star \star}$ & $0.19^{\star \star}$ & $-0.07^{\star \star}$ \\
\hline Kvinne & $0.05^{\star \star}$ & 0.01 & $0.11^{\star \star}$ & $0.04^{\star \star}$ \\
\hline Alder/100 & $0.41^{\star \star}$ & 0.03 & $0.58^{\star \star}$ & 0.05 \\
\hline Aldri-gift & & $0.16^{\star \star}$ & & $0.14^{\star \star}$ \\
\hline Skilt & & $0.10^{\star \star}$ & & $0.11^{\star \star}$ \\
\hline Enke/enkemann & & $0.10^{\star \star}$ & & $0.15^{\star \star}$ \\
\hline Barn (0-3) & & -0.00 & & $-0.02^{\star \star}$ \\
\hline Økonomisk situasjon (1-5) & & $-0.03 \star \star$ & & $-0.05^{\star \star}$ \\
\hline Utdanning (1-3) & & -0.01 & & $-0.02^{\star \star}$ \\
\hline Yrkesaktiv & & $-0.05^{\star \star}$ & & $-0.04^{\star \star}$ \\
\hline Helse (1-5) & & $-0.12^{\star \star}$ & & $-0.10^{\star \star}$ \\
\hline $\mathrm{R}^{2}$ & .04 & .14 & .04 & .15 \\
\hline
\end{tabular}

${ }^{\star} \mathrm{p}<.05,{ }^{\star \star} \mathrm{p}<.01$

svært lavt depresjonsnivå. Den endelige modellen indikerer også at høy alder ikke er relatert til ensomhet og depresjon når det tas hensyn til aldersrelaterte tap knyttet til helse, økonomi og sivilstatus.

\section{Diskusjon}

I denne artikkelen har vi søkt å gi svar på om ulike livsbetingelser og forutsetningene for aktiv og god aldring lar seg oversette til regionale skiller i utbredelsen av ensomhet og depresjon blant eldre i Europa. Vi finner et tydelig Øst-Vest skille, med forekomster av ensomhet og depresjon opptil tre-fire ganger høyere blant eldre personer (60-80 år) i østeuropeiske enn i nordvesteuropeiske land. I de tidligere 
kommuniststatene i utvalget rapporterer mellom $23 \%$ og $43 \%$ av eldre et ganske alvorlig nivå av ensomhet, langt flere enn de $8-13 \%$ som er ensomme blant deres jevnaldrende i Vest. Tilsvarende rapporterer 20-31 \% i Øst og 11-18 \% iVest depressive symptomer. Disse forskjellene observeres kun i de eldste aldergruppene. Det er få og små landsforskjeller i ensomhet og depresjon blant yngre voksne og personer i midtlivet. Den generelt lave livskvalitet blant eldre i Øst-Europa synes å speile en høy eksponering for stressorer som fattigdom, helseproblemer og tap av venner og kjære. Kanskje særlig når stressorer opptrer samtidig vil de bidra til psykiske plager ved å begrense mulighetene for sosial omgang, selvhjulpenhet og følelse av mening, egenverdi, og optimisme. De samme forhold reduserer samtidig muligheten til forbedring for de som har blitt ensomme eller deprimerte.

\section{Velferdsstatens rolle}

Aldersrelaterte økninger i ensomhet og depresjon fra midtlivet til eldre år synes å være sterkere og opptre tidligere $\mathrm{i}$ land med dårligere levekår og velferdsordninger. At livskvaliteten blant eldre varierer systematisk med ulike velferdsindikatorer på landnivå peker i retning av at sosialpolitikk kan påvirke forhold som bidrar til ensomhet og depresjon, som helse, sosial deltakelse, sosial forankring og sosioøkonomiske ressurser. Nærmere bestemt kan moderne velferdsstater forhindre eller redusere psykiske helseproblemer gjennom bedre helse- og sosialtjenester, inntekts- og boligforhold, kollektivtransport og gjennom å bidra til å støtte familieomsorgsgivere og å skape trygge lokalmiljø. Ved å gi et sikkerhetsnett, kan slike velferdsregimer også fremme en følelse av sikkerhet, håp og optimisme, noe som igjen kan redusere bekymring og psykisk uro. Velferdsordninger har særlig betydning for eldre med helsemessige begrensninger eller lave sosioøkonomiske ressurser (Hansen et al., 2017). Høy ensomhet og depresjon i de tidligere sosialistiske landene må ses i sammenheng med at formelle velferdsstrukturer er svake eller fraværende i mange av disse landene (Lipsitz, 2005). Når det finnes lite tjenester kan omsorgsoppgaver være tyngre og bidra til at man i større grad blir isolert i familien (Herlofson et al., 2019).

Gode velferdsordninger kan også bidra til å støtte opp under eldres muligheter til å delta sosialt og produktivt i samfunnet. Eldre i Øst kan derfor i mindre grad ha roller og oppgaver som knytter dem til samfunnet. Vi ser at eldre i Vest langt oftere er yrkesaktive, og at aktiviteten er knyttet til lavere ensomhet og depresjon. Et økende antall pensjonister i Øst opplever dessuten alvorlig økonomiske bekymringer på grunn av økt inflasjon og redusert pensjonsverdi (Botev, 2012). Mange har verken råd eller tilgang til nødvendige helsetjenester. Det kan også være mer sosialt akseptert å bli behandlet for psykiske lidelser i de vestlige landene. Det at behandling ikke bare er mer tilgjengelig men også mer vanlig og normalisert kan bidra til å forklare de lave depresjonsratene i de vestlige landene. Politisk omveltning, økonomisk usikkerhet og betydelig sosioøkonomisk ulikhet i Øst kan også ha svekket følelsen av tillit og sosial integrasjon, som igjen kan øke risikoen for depresjon og ensomhet blant eldre i regionen. 
Det bør understrekes at det er store landsforskjeller i ensomhet og depresjon innad i regionene, særlig i Øst. Forekomstene av plager er gradvis lavere jo høyere økonomisk velstand og jo rausere velferdsordninger. Polen representerer et sentraleller østeuropeisk land som synes å ha samme forekomst av psykiske plager blant eldre som de nordvesteuropeiske landene. Tsjekkia ligger et sted mellom de vestlige og østlige landene. Vi kan altså snarere prate om en gradient, hvor land med lavere velstand og velferdsordninger kommer dårligere ut, enn et klart Øst-Vest skille hva gjelder livskvalitet i eldre år i Europa.

\section{Kulturelle forklaringer?}

Landsforskjeller i ensomhet lar seg imidlertid ikke fullt ut forklare ved levevilkår og individuelle risikofaktorer. Det kan derfor være interessant å se variasjonen i et kulturelt perspektiv. Sør- og Øst-Europa er generelt preget av en mer familiær og kollektivistisk orientering enn de mer individualistiske nordvesteuropeiske landene (Herlofson et al., 2019; Reher, 1998; Saraceno \& Keck, 2010). Land med mer individualistisk orienterte verdier er også preget av høyere andel aleneboende, høyere skilsmisserater, lavere fruktbarhet og mindre familienettverk. En vanlig antakelse er derfor at det vil være mindre sosial kontakt og sosial støtte, og mer sosial isolasjon og ensomhet i individualistiske og mindre familistiske kulturer (Dykstra, 2009). Det er således et paradoks at ensomheten blant eldre er lavest i nettopp disse kulturene.

Flere forfattere peker på betydningen av å vurdere folks referanseramme og normative orientering i den kulturelle konteksten (Johnson \& Mullins, 1987; Jylhä \& Jokela, 1990). Ensomhet oppstår når kvaliteten på ens sosiale relasjoner faller under forventet eller ønsket kvalitet for sosial kontakt. Johnson og Mullins (1987) introduserte begrepet «ensomhetsterskel» for å referere til nivået der ensomhet oppstår. Sør- og østeuropeere kan ha en lavere ensomhetsterskel enn andre europeere på grunn av høyere forventninger til sterke familie- og lokalmiljøbånd. De høye forventningene til sterke bånd kan øke følelsen av ensomhet dersom disse forventningene ikke blir oppfylt. En lav ensomhetsterskel kan giøre det verre for eldre (hvorav de fleste er kvinner) i land med synkende barnetall, økende utvandring og høy risiko for enkestand.

Også andre hypoteser har blitt lansert for å forklare landvariasjoner i eldres ensomhet. Det har blitt foreslått at mange eldre østeuropeere, fordi de har levd under kommunistisk styre der borgernes behov generelt ble dekket av staten, kan føle seg mer usikre når det gjelder egne evner og mestringsressurser (Rokach, 2007). Det har også vært foreslått at seniorer i tidligere sosialistiske land kan være mer ensomme fordi de ikke er vant til å klare seg selv og deres lavere selvstendighet gjør dem mer sårbare overfor svekkelser og tap knyttet til helse og sosiale relasjoner som følger med det å bli gammel (Dykstra, 2009).

Endelig kan det tenkes at en "klagekultur» (litany of suffering) - en måte å artikulere og håndtere håpløsheten og usikkerheten som fulgte med overgangen til 
kapitalisme på - også bidrar til at folk i tidligere kommuniststater rapporterer høyere nivåer av ubehag (Pietilä \& Rytkönen, 2008).

\section{Begrensninger}

Denne studien benytter et datamateriale som er særlig velegnet til å bidra til forskningsfeltet på europeiske skiller i eldres livskvalitet. GGS dataene består av harmoniserte og landsrepresentative data fra flere østeuropeiske land, en region som i liten grad har vært studert i feltet tidligere. En ytterligere styrke er at GGS har to validerte flerleddsinstrument som måler ensomhet og depresjon, to komplekse fenomen som dekker viktige aspekter ved livskvaliteten og som har vidtgående implikasjoner for både ens egen og nærpersoners helse, trivsel og fungering. Datamaterialet har imidlertid også visse begrensninger som bør nevnes. For eksempel har flere land lav svarprosent, som Litauen (37 \%) og Belgia (42\%). Lav svarprosent kan bety at forekomsten av psykiske plager er særlig underestimert i disse landene. En annen svakhet er at GGS mangler land fra Sør-Vest Europa. Vi kan derfor ikke svare på om livskvaliteten i Øst er lavere enn i Sør-Vest. Videre kunne vi ønsket å studere positive indikatorer på livskvalitet, som lykke og livstilfredshet. Dessuten har GGS for få land til å utføre flernivåanalyser. Med slike analyser kunne vi belyst sammenhenger mellom forekomstene og ulike faktorer på landsnivå, som sosial kapital, velstandsnivå og helse- og pensjonsutgifter. GGS har også mangler knyttet til forklaringsfaktorer på individnivå. Det kunne for eksempel vært interessant å studere (flere) indikatorer på sosiale roller og aktiv aldring (frivillighet, politisk deltakelse, omsorgsansvar), sosial tilhørighet (omgang med venner, sosial kontakt) og psykologisk fungering (mestring, trygghet, optimisme). Data om hvorvidt folk er i medisinsk eller psykologisk behandling for depresjon ville også vært interessant. Trolig er det store landsforskjeller i hvorvidt slik behandling er tilgjengelig, akseptert og benyttet, og disse kan bidra til å forklare de ulike depresjonsratene vi finner.

En annen begrensning knytter seg til sammenlignbarheten av aldersgrupper i land med ulik forventet levealder. Det kan for eksempel være at ensomhet er «stabil til veldig høy alder» (Dykstra, 2009), men at "veldig høy alder» inntrer tidligere $\mathrm{i}$ land med lavere levealder. Vi klarer ikke å korrigere for denne muligheten ved å kontrollere for helse og sivilstand. Ideelt sett burde vi kontrollere for andre aspekt ved biologisk (objektiv helse), psykologisk (kognisjon, minne, kontroll) og sosial aldring (nettverk og tilgang på støtte). For å sammenligne personer i omtrent samme livsfase har vi i en tidligere studie analysert personer som er opp til 10 år yngre enn gjennomsnittlig levealder i respektive land (for eksempel, hvis forventet levealder er lik 78 benyttes aldersgruppen 68 til 78) (Hansen \& Slagsvold, 2016). Funnene viser fortsatt store landsforskjeller, men de er noe mindre enn de som er vist her med alder 60-80. Merk også at plagene vi studerer er klart mer utbedt blant middelaldrende i Øst enn eldre i Vest. 


\section{Avsluttende kommentar}

I Norge og andre vestlige land er ensomhet og depresjon ikke spesielt utbredt $i$ eldre år (opptil 80 år). Om lag 5-15\% - omtrent like mange som blant yngre voksne rapporterer om alvorlige problemer. I mange østeuropeiske land, derimot, tyder data på at opptil en tredjedel av eldrebefolkningen er ensomme og/eller har depressive plager. Det er viktig å huske at forekomstene trolig er underestimert fordi problemene vanligvis er større blant de vi ikke fanger opp i surveyundersøkelser - de skrøpeligste og de eldste.

Betydningen av å forebygge og redusere psykisk ubehag strekker seg utover det rent emosjonelle. Ensomhet og depresjon ser ut til å fremskynde fysiologisk og kognitiv svekkelse og øke behovet for helse- og omsorgstjenester (Fiske et al., 2009; Hawkley et al., 2008). Å motvirke disse plagene er derfor viktig for både enkeltpersoner og samfunn, og kostnadene ved ensomhet og depresjon kan forverre kostnadene ved befolkningsaldring, spesielt i de østeuropeiske landene. For disse landene vil det å holde helseutfordringer høyt på dagsordenen i en tid med stor økonomisk usikkerhet være krevende, men likevel viktig for å styrke befolkningens helse. Kombinasjonen av økonomisk og sosial belastning og en aldrende befolkning innebærer potensielt større psykisk skade for et stort antall eldre mennesker. Det kan også være negative spiralvirkninger ettersom deprimerte og ensomme mennesker generelt er mindre sosialt engasjerte og prososiale i sin oppførsel, noe som igjen kan påvirke mental helse i sosiale nettverk og lokalmiljø.

Resultatene av denne studien forteller om svært ulike betingelser for aldring og indikerer alvorlige problemer blant eldre i enkelte europeiske land. Mens eldre i Vest har relativt gode betingelser for aktiv aldring, og det i vestlige land er mer politisk fokus på at eldre bruker sine ressurser aktivt i samfunnet, synes det som om grunnleggende betingelser for deltagelse og integrasjon blant eldre er langt dårligere i Øst. Plager med ensomhet og depresjon vil dessuten i seg selv virke i retning av å forsterke passivitet og avhengighet i alderdommen.

\section{Finansiering}

Arbeidet med artikkelen er finansiert av Norges forskningsråd gjennom prosjektet «Active ageing - pathways and outcomes» (prosjektnr. 236997).

\section{Referanser}

Blazer, D. (2003). Depression in late life: Review and commentary. Fournals of Gerontology Series a-Biological Sciences and Medical Sciences 58, 249-65.

Botev, N. (1999). The political economy of population ageing. European fournal of Population-Revue Europeenne De Demographie 15, 204-05.

Botev, N. (2012). Population ageing in Central and Eastern Europe and its demographic and social context. European fournal of Ageing 9, 69-79.

Castro-Costa, E., Dewey, M., Stewart, R. \& Prince, M. (2007). Prevalence of depressive symptoms and syndromes in later life in ten European countries - the SHARE study. British fournal of Psychiatry 191, 393-401. 
Central Intelligence Agency. (2014). World factbook. www.cia.gov/library/publications/download/download2014/index.html

De Jong Gierveld, J., Dykstra, P. \& Schenk, N. (2012). Living arrangements, intergenerational support types and older adult loneliness in Eastern and Western Europe. Demographic Research 27, 167-99.

De Jong Gierveld, J. \& van Tilburg, T. (2010). The De Jong Gierveld short scales for emotional and social loneliness: Tested on data from 7 countries in the UN generations and gender surveys. European fournal of Ageing 7, 121-30.

De Jong Gierveld, J., van Tilburg, T. \& Dykstra, P. (2006). Loneliness and social isolation. I A. Vangelisti \& D. Perlman (Red.), Cambridge handbook of personal relationships (s. 160-183). Cambridge: Cambridge University Press.

Deaton, A. (2007). Income, aging, health and wellbeing around the world: Evidence from the Gallup World Poll. National Bureau of Economic Research, Inc.

Dykstra, P. (2009). Older adult loneliness: Myths and realities. European fournal of Ageing 6, 91-105.

Eurostat. (2013-2014). https://ec.europa.eu/eurostat/

Fiske, A., Wetherell, J. \& Gatz, M. (2009). Depression in older adults. Annual Review of Clinical Psychology 5, 363-375.

Fokkema, T., Gierveld, J. D. J. \& Dykstra, P. (2012). Cross-national differences in older adult loneliness. fournal of Psychology 146, 201-28.

Fokkema, T., Kveder, A. \& Liefbroer, A. (2014). Report and recommentations for sample and data adjustment procedures. GGP report.

Fokkema, T., Emery, T., Kveder, A., Liefbroer, A. \& Hiekel, N. (2016). Generations and Gender Programme Wave 1 data collection: An overview and assessment of sampling and fieldwork methods, weighting prodecures, and cross-sectional representativeness. Demographic Research 34, 499-524.

Generations and Gender Survey. (2005-2008). Contextual database. www.ggp-i.org

Hansen, T. \& Slagsvold, B. (2011a). Alder. I S. Næss, T. Moum \& J. Eriksen (Red.), Livskvalitet. Forskning om det gode liv (s. 128-143). Bergen: Fagbokforlaget.

Hansen, T. \& Slagsvold, B. (2011b). An evaluation of the existing psychological instruments in the GGS and propositions for a new module. GGP report.

Hansen, T. \& Slagsvold, B. (2012). The age and subjective well-being paradox revisited: A multidimensional perspective. Norsk Epidemiologi 22, 187-95.

Hansen, T. \& Slagsvold, B. (2016). Late-life loneliness in 11 European countries: Results from the Generations and Gender Survey. Social Indicators Research 129, 445-64.

Hansen, T. \& Slagsvold, B. (2017). The East-West divide in late-life depression in Europe. Scandinavian Psychologist 4, e4.

Hansen, T., Slagsvold, B. \& Veenstra, M. (2017). Educational inequalities in late-life depression across Europe. European fournal of Ageing 14, 407-418.

Hawkley, L., Hughes, M. \& Cacioppo, J. (2008). From social structural factors to perceptions of relationship quality and loneliness: The Chicago health, aging, and social relations study. fournals of Gerontology Series B-Psychological Sciences and Social Sciences 63, 375-384.

Hellevik, O. (2009). Linear versus logistic regression when the dependent variable is a dichotomy. Quality $\mathcal{E}$ Quantity 43, 59-74.

Herlofson, K., Daatland, S. \& Veenstra, M. (2019). Generasjoner imellom. Holdninger til familiens ansvar øst og vest i Europa. Nordisk Østforum 33, 1-20.

Johnson, P. \& Mullins, L. (1987). Growing old and lonely in different societies: Toward a comparative perspective. Fournal of Cross-Cultural Gerontology 2, 257-75.

Jylhä, M. \& Jokela, J. (1990). Individual experiences as cultural - a cross-cultural study on loneliness among the elderly. Ageing \& Society 10, 295-315.

Kok, R., Avendano, T. \& Mackenbach, J. (2012). Can reporting heterogeneity explain differences in depressive symptoms across Europe?. Social Indicators Research 105, 191-210.

Laaksonen, M. (2001). Do health behaviour and psychosocial risk factors explain the European East-West gap in health status?. European fournal of Public Health 11, 65-73.

Lipsitz, L. (2005). The elderly people of Post-Soviet Ukraine: Medical, social, and economic challenges. Fournal of the American Geriatrics Society 53, 2216-2220.

McDowell, I. (2006). Measuring health: A guide to rating scales and questionnaires. New York: Oxford University Press.

Moor, N. \& Komter, A. (2012). Family ties and depressive mood in Eastern and Western Europe. Demographic Research 27, 201-32. 
OECD (2012). International migration outlook 2014. OECD Publishing.

Pietilä, I. \& Rytkönen, M. (2008). Coping with stress and by stress: Russian men and women talking about transition, stress and health. Social Science \& Medicine 66, 327-38.

Pinquart, M. \& Sorensen, S. (2001). Influences on loneliness in older adults: A meta-analysis. Basic and Applied Social Psychology 23, 245-66.

Radloff, L. S. (1977). The CES-D scale: A self-report depression scale for research in the general population. Applied Psychological Measurements 1, 385-401.

Reher, D. S. (1998). Family ties in western Europe: Persistent contrasts. Population and Development Review, 24(2), 203-234.

Rokach, A. (2007). The effect of age and culture on the causes of loneliness. Social Behavior and Personality $35,169-86$.

Saraceno, C., \& Keck, W. (2010). Can we identify intergenerational policy regimes in Europe? European Societies, 12(5), 675-696.

Shafer, A. B. (2006). Meta-analysis of the factor structures of four depression questionnaires: Beck, CES-D, Hamilton, and Zung. Fournal of Clinical Psychology 62, 123-46.

Sletten, M. \& Bakken, A. (2016). Psykiske helseplager blant ungdom - tidstrender og samfunnsmessige forklaringer. Oslo: NOVA.

Slagsvold, B., Veenstra, M., Daatland, S. O., Hagestad, G., Hansen, T., Herlofson, K., ... Solem, P. E. (2012). Life-course, ageing and generations in Norway: The NorLAG study. Norwegian fournal of Epidemiology 22, 95-102.

Sundstrom, G., Fransson, E. \& Malmberg, B. (2009). Loneliness among older Europeans. European fournal of Ageing 6, 267-75.

Sutin, A., Terracciano, A. \& Milaneschi, Y. (2013). The trajectory of depressive symptoms across the adult life span. Fama Psychiatry 70, 803-11.

Tornstam, L. (2007). Stereotypes of old people persist. A Swedish "facts on aging quiz" in a 23-year comparative perspective. International fournal of Ageing and Later Life 2, 33-59.

Van de Velde, S., Bracke, P., \& Levecque, K. (2010). Gender differences in depression in 23 European countries. Cross-national variation in the gender gap in depression. Social Science \& Medicine 71, 305-313.

Vikat, A., Spéder, Z., Beets, G., Billari, F., Bühler, C., Désesquelles, A., \& Solaz, A. (2007). Generations and Gender Survey (GGS): Towards a better understanding of relationships and processes in the life course. Demographic Research 17, 389-439.

WHO. (1993). The ICD-10 classification of mental and behavioral disorders. Diagnostic criteria for research. Geneva: World Health Organization.

World Databank. (2008-2013). https://data.worldbank.org

Yakovlev, E. (2015). Alcoholism and mortality in Eastern Europe. IZA World of Labor.

Yang, K. M. \& Victor, C. (2011). Age and loneliness in 25 European nations. Ageing E Society 31, $1368-88$. 


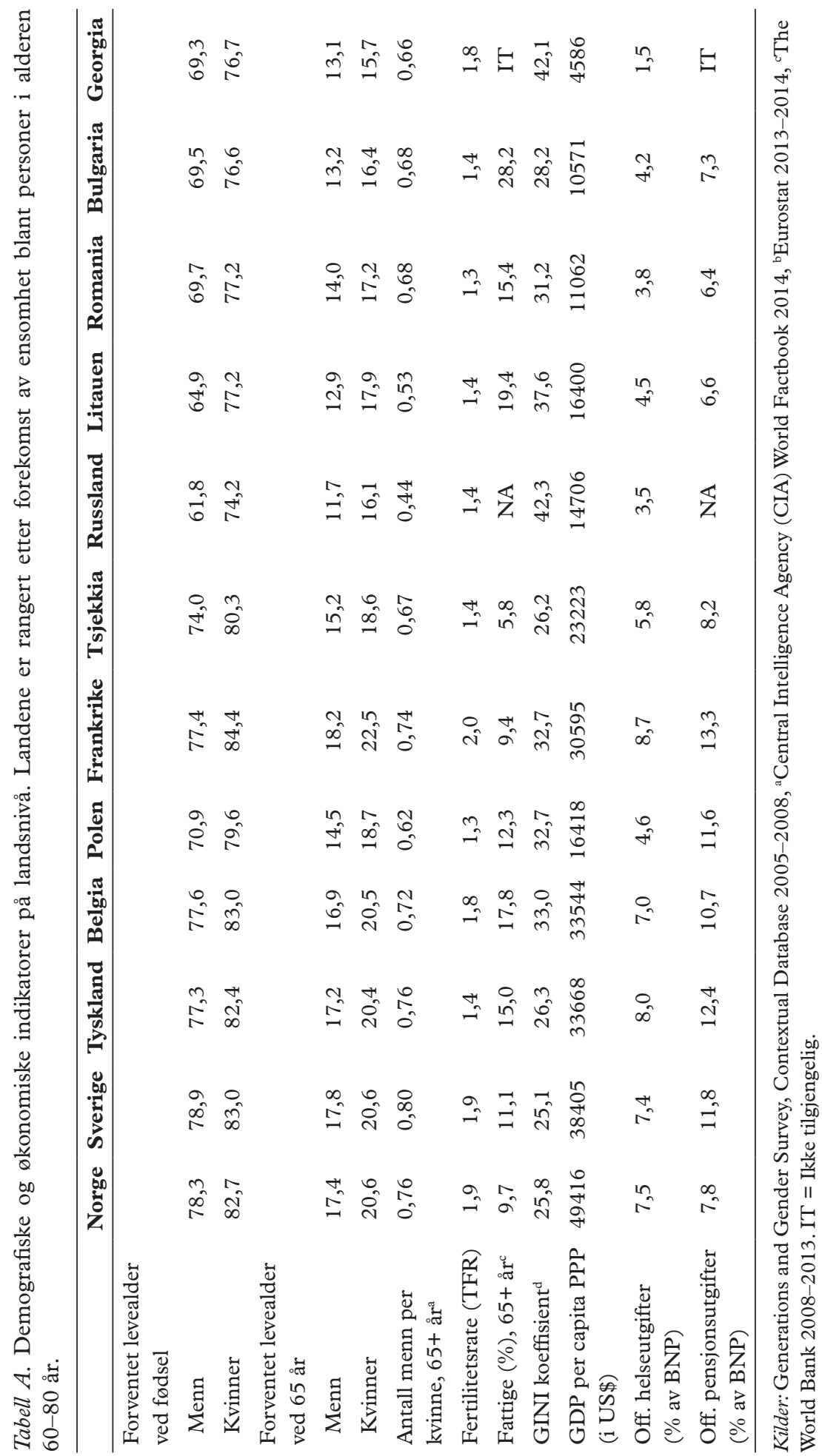

